\title{
Prehospital Factors Affecting the Intracerebral Hemorrhage Stroke Patient Outcomes in the Emergency Department of Saiful Anwar Hospital Malang
}

\author{
Aullia Dewi $^{1} \quad$ M. Istiadjid Edy Santoso ${ }^{3} \quad$ Yuddy Imowanto $^{2} \quad$ Nanik Setijowati $^{3}$ \\ 1.Emergency Medicine Residency, Emergency Medicine, Universitas Brawijaya \\ 2.Teaching Staff of Emergency Medicine, Faculty of Medicine, Universitas Brawijaya \\ 3.Teaching Staff of Public Health Science, Faculty of Medicine, Universitas Brawijaya
}

\begin{abstract}
Introduction: In 2001, intracerebral hemorrhage (ICH) incidence rate in Indonesia was 18.5\%. Globally, the mortality rate in the first year was $55 \%{ }^{1,2,9}$. Th

is research was conducted to find out whether pre-hospital factors (age, initial prehospital treatment, GCS) affected ICH patient outcomes.

Methods: This is analytical observational research. After 3 months, the outcomes were assessed using the Glasgow Outcome Scale. 60 patients, who were the samples, were collected from August 2018 to January 2019 at Saiful Anwar Government General Hospital Malang.

Results: There was no significant relationship among age, prehospital initial treatment, and outcomes; there was a relationship between GCS and patient outcomes $(\mathrm{p}=0.04)$.

Conclusion: Prehospital factors such as age and prehospital initial treatment did not affect ICH patient outcomes since they did not have a direct effect on reducing intracranial pressure. GCS was related to patient outcomes because it was a determining predictor of ICH patients' mortality and morbidity.
\end{abstract}

Keywords: Prehospital factors, prehospital initial treatment, age, GCS, intracerebral hemorrhage (ICH), outcomes, Glasgow Outcome Scale.

DOI: $10.7176 / \mathrm{JHMN} / 65-05$

Publication date: August $31^{\text {st }} 2019$

\section{Introduction}

Stroke is an acute neurological deficit disease; a spontaneous occurrence of the brain blood vessel disorder can cause disability and/or death/ Cerebro Vascular Disease (CVD). It includes ischemic and hemorrhagic (bleeding) strokes. Ischemia is divided into thrombosis, embolism, and stroke due to hypoperfusion, while hemorrhage (bleeding) is divided into intracerebral and subarachnoid hemorrhage (about 3\%) ${ }^{9}$. In developing countries, stroke is the 3rd leading cause of death after coronary heart disease and cancer. There are around 13 million new stroke patients every year, and around 4.4 million deceases ${ }^{1,9}$. Moreover, Indonesia experiences an increase in disability and death; based on the patients' age, $15.9 \%$ occurs to 45 to 55 -year-olds, $26.8 \%$ occurs to the 55 to 65 -year-olds, and $23.5 \%$ occurs to the $>65$-year-olds. ${ }^{6.7}$ Saiful Anwar Hospital Malang (also known as 'RSSA') is a class-A government hospital in East Java Province, as well as a teaching and referral hospital serving around 30367 patients/year, or around 83.14 patients/day. Furthermore, at least 2 new stroke patients visit each day, with or without referrals. ${ }^{5}$

In Indonesia, patients are often taken to the hospital by families or people who do not understand the principle of Basic Life Support (BLS) and another alternative such as an emergency call to the Emergency Medical Service (EMS) ${ }^{10}$ EMS is an extension of emergency medical care that attends to and takes patients in the prehospital stage. In the late 1960s-1970s, non-prehospital personnel began to learn advanced medical skills, including infusion, drug administration, as well as interpretation of heart rhythm and defibrillation. ${ }^{9}$ EMS and prehospital systems in Indonesia have not developed well; it adopts the 'load and go' strategy since the emergency education is based on the American College of Emergency Physician (ACEP). ${ }^{10}$

Stroke patients' family will urgently take them to the hospital in a private vehicle or call an ambulance, so that patients receive immediate treatment, and are expected to show better outcomes. The family's lack of knowledge about the disease or their inability to pay hospital cost leads to self-treatment at home using improvised equipment; this surely affects the process of the patient's treatment and healing. There is only a few data of ICH stroke patient outcome reviewed based on prehospital factors. Research is needed to learn whether prehospital factors such as patients' prehospital initial treatment before being taken to RSSA, age, and consciousness (GCS) affect patient outcomes for the next 3 months according to Glasgow Outcome Scale (death, vegetative state, severe disability, moderate disability, and mild disability).

\section{Objectives}

The research aims at analyzing whether prehospital factors (patients' initial treatment before being taken to RSSA, age, and consciousness) affect intracerebral hemorrhagic stroke patient outcomes in RSSA emergency department 
and analyzing the most dominant factors.

\section{Methods}

This is analytical observational research using the cross-sectional study to find out the relationship between prehospital initial treatment, age, and GCS affecting the intracerebral hemorrhage/ ICH outcomes. The population was all stroke patients in the emergency department of RSSA Malang; the samples included the Triage P1 category and were according to the inclusion criteria during the research period. Samples were collected using the consecutive technique based on the inclusion criteria (patients' age were 20-60 years old and ICH score was 0-4), and P2 or P3 (non-critical and/or non-emergency); whereas uncooperative patients in the process of collecting data (those who were out of reach, or changed their phone numbers) were included in the drop out criteria.

\section{Results}

The research began in August-January 2019 using samples of 60 intracerebral hemorrhage stroke patients. The data were collected since the patients were in triage and were interviewed with their families via telephone to fill in the questionnaire (it was conducted according to the ethical rules). The dependent variable was the outcomes of intracerebral hemorrhage stroke patients attending RSSA, observed with the Glasgow Outcome Scale score after 3 months. The outcomes were grouped into 2 categories: bad outcomes (death, vegetative state, and severe disability) and good outcomes (moderate and mild disability). The independent variables were patients' initial treatment (with or without receiving an initial treatment), consciousness (divided into poor GCS / GCS 3-4, moderate GCS / GCS 5-12, good GCS / GCS 13-15), and age (adults $<80$ years old and elderly $\geq 80$ years old).

Table 1. The relationship between sex, prehospital management, age and GCS with the outcomes and results of the analysis

\begin{tabular}{|c|c|c|c|c|c|c|}
\hline \multirow{3}{*}{ NO } & \multirow{3}{*}{ VARIABLE } & \multicolumn{4}{|c|}{ OUTCOME } & \multirow{3}{*}{$\mathrm{P}$} \\
\hline & & \multicolumn{2}{|c|}{$\begin{array}{l}\text { DECEASED + VEGETATIVE STATE } \\
+ \text { SEVERE DISABILITY }\end{array}$} & \multicolumn{2}{|c|}{$\begin{array}{l}\text { MODERATE DISABILITY } \\
+ \text { MILD DISABILITY }\end{array}$} & \\
\hline & & $\mathrm{N}$ & $\%$ & $\mathrm{~N}$ & $\%$ & \\
\hline \multirow[t]{3}{*}{1.} & Sex & & & & & \\
\hline & Male & 34 & 56,7 & 4 & 6,7 & $0,09^{a}$ \\
\hline & Female & 16 & 26,7 & 6 & 10 & \\
\hline \multirow[t]{4}{*}{2.} & Treatment & & & & & \\
\hline & None & 14 & 23,3 & 3 & 5 & $0,95^{\mathrm{a}}$ \\
\hline & $1-3$ & 5 & 8,3 & 0 & 0 & $0,57^{\mathbf{b}}$ \\
\hline & $>3$ & 31 & 51,7 & 7 & 11,7 & ref. \\
\hline \multirow[t]{4}{*}{3.} & GCS & & & & & \\
\hline & $3-4$ & 4 & 6,7 & 0 & 0 & $0,26^{\mathrm{b}}$ \\
\hline & $5-12$ & 38 & 63,3 & 5 & 8,3 & $0,04^{\mathrm{b} *}$ \\
\hline & $13-15$ & 8 & 13,3 & 5 & 8,3 & ref. \\
\hline
\end{tabular}

There were more male patients with bad outcomes than female (only 16 women), and more for male patients with good outcomes than female. Pertaining to the variable of prehospital treatment, $>3$ patients resulted in 31 bad outcomes, patients receiving no initial treatment resulted in 14 bad outcomes, while 1-3 patients' receiving initial treatment resulted in 5 bad outcomes; accordingly, this showed an insignificant relationship. Furthermore, the variable of GCS 5-12 resulted in 38 patients with bad outcomes $(\mathrm{p}=0.04)$, whereas GCS 5-12 and GCS 13-15 revealed the same number of good outcomes, which was 5 patients. 
Table 2. The relationship between age and GCS variables with the outcomes

\begin{tabular}{|c|c|c|c|c|c|c|c|c|c|}
\hline No & VARIABLE & OUTCOME & $\mathbf{N}$ & MEAN & SD & MED & MIN & MAX & $\mathbf{P}$ \\
\hline \multirow[t]{2}{*}{1.} & $\mathrm{AGE}$ & $\begin{array}{l}\text { Deceased }+ \\
\text { Vegetative state }+\end{array}$ & 50 & 52,5 & 6,6 & 54 & 26 & 60 & \multirow{2}{*}{$0,61^{\mathrm{b}}$} \\
\hline & & $\begin{array}{l}\text { Severe disability } \\
\text { Moderate disability+ } \\
\text { Mild disability }\end{array}$ & 10 & 54,1 & 4,8 & 55 & 45 & 60 & \\
\hline \multirow[t]{2}{*}{2.} & GCS & $\begin{array}{l}\text { Deceased }+ \\
\text { Vegetative state }+\end{array}$ & 50 & 9,1 & 3,1 & 9 & 3 & 15 & \multirow[b]{2}{*}{$0,05^{\mathrm{a} *}$} \\
\hline & & $\begin{array}{l}\text { Severe disability } \\
\text { Moderate disability+ } \\
\text { Mild disability }\end{array}$ & 10 & 12,3 & 2,8 & 12,5 & 7 & 15 & \\
\hline
\end{tabular}

Explanation a: T-test $\quad$ b: Mann-Whitney test $\quad *=$ significant if $\mathrm{p}<0,005$

The average patients' GCS with bad outcomes was 9.1, with a minimum GCS of 3; while patients with good outcomes, the average GCS was 12.3, with a minimum GCS of 7. In both groups, the outcome of maximum GCS when patients arrived was 15 and the result of data processing showed a significant relationship $(p=0.005)$.

\section{Discussion}

Prehospital initial treatments might be in the form of oxygen therapy administration, intravenous administration, fluids administration, gastric tube insertion, urinary insertion, and further action of ETT placement. However, the initial treatment does not have a direct effect on PIS disease, because it is an additional treatment aiding and supporting the main therapy, which is surgery. Similar to research in Taiwan, patients with referral system will experience a delay in reaching the referral hospital and getting significant treatment. If the first-level health facility supports treatment and therapy for acute stroke, $50 \%$ of patients can be immediately screened for thrombolytic therapy because intravenous thrombolysis has been applied in Taiwan since November 2002 and to almost all patients $(93.4 \%)$ brought by emergency ambulance to the emergency department at a referral hospital. ${ }^{3}$

According to the standard ICH therapy (surgery), for ICH occurred close to the surface can be treated surgically, while ICH in the deep area of the brain, for example in the patient's pons, will be treated conservatively. 29 out of 60 patients had poor outcomes as they refused surgery due to financial problems; additionally, the outcomes are affected by the non-operable ICH location factor.

Juvela S. presented that a significant predictor of $\mathrm{CIH}$ patient mortality was early patient's GCS at hospital admission $(p<0.001)$ and the presence of subcortical hematomas $(p<0.05)^{4}$. The mortality rate in the first 6 months after ICH was between 23-58\%. Low GCS, heavy bleeding volume, IVH appeared on initial CT scan are factors consistently identified as the prediction of high mortality rate ${ }^{2}$. Surgery is still the best treatment for intracerebral hemorrhage patients admitted to the hospital with GCS scores of $<14$ or bleeding with a volume of $\geq 40 \mathrm{ml}$. However, patients with an initial GCS of $\geq 14$ and $<40 \mathrm{ml}$ bleeding showed good outcomes, which were a mild or moderate disability so that therapy can be continued conservatively.

From the results of the research, it was found that the average age of CIH patients who were deceased or severely disabled in RSSA was 52.5 years old; this was almost the same as the patients with moderate or mild disability, which was 54.1 years old $(\mathrm{p}=0.61)$. It is similar to the survey conducted in 28 hospitals throughout Indonesia, describing that there are more male patients than female. The patients' age profile of 45 year-olds is $11.8 \%, 45-64$ year-olds is $54.2 \%$, and $>65$ year-olds is around $33.5 \%$; this means that the patients' age who experienced bleeding strokes is almost evenly distributed in several ranges. Based on the data of 'Riskesdas Kemenkes Republik Indonesia' (Basic Health Research of The Ministry of Health of The Republic of Indonesia) in 2018, stroke incidence in the population of $>15$-year-old males is 11.0 , and of the female patients' is $10.9^{8}$.

\section{Conclusion}

From the research results, it was concluded that:

1. The prehospital factors in this study, which were the patient's initial treatment, time, age, did not affect the intracerebral hemorrhage patient's outcomes.

2. The patient's consciousness measured by GCS is related to a CIH patient's outcomes because early GCS acts as a predictor of patient mortality.

There are several limitations in this research, one of which is the small number of samples. Therefore, more studies with larger samples of stroke patients are needed, expecting that mortality and morbidity in Indonesia can be decreased. 


\section{References}

1. Anderson CS, Heeley E, Huang Y, 2013. Rapid Blood-Pressure Lowering in Patients with Acute Intracerebral Hemorrhage. New England Journal of Medicine, 368: 2355

2. Broderick J, et al., 1993. Volume of Intracerebral Hemorrhage A Powerful And Easy-To-Use Predictor Of 30-Day Mortality. Stroke 24: 987-993

3. Chang K, Tseng M, Tan T, 2004. Prehospital Delay after Acute Stroke in Kaohsiung, Taiwan. Stroke, American Heart Association, 11: 700-05

4. Juvela S, 1995. Risk Factors for Impaired Outcome after Spontaneous Intracerebral Hemorrhage. Arch Neurology (12) : 1193-202

5. Laporan Tahunan Rumah Sakit Saiful Anwar, 2017.

6. Misbach J, Ali W, 2012. Stroke Di Indonesia: A First Large Prospective Hospital-Based Study of Acute Stroke in 28 Hospitals in Indonesia. Journal of Clinical Neuroscience, 8: 245-249

7. Riskesdas Depkes. 2013. Badan Penelitian Dan Pengembangan Kesehatan Dasar Kementrian Kesehatan Republik Indonesia. Jakarta

8. Riskesdas Depkes. 2018. Badan Penelitian Dan Pengembangan Kesehatan Dasar Kementrian Kesehatan Republik Indonesia. Jakarta

9. Tintinalli JE \&Stapczynski JS, 2011. Tintinalli's Emergency Medicine: A Comprehensive Study Guide. New York, McGraw-Hill

10. Triwibowo H, Setyawan OE, 2015. Gambaran Tentang Persepsi Masyarakat Terhadap Pertolongan Pertama Pada Kecelakaan Lalu Lintas Di Desa Sawo Kecamatan Jetis Kabupaten Mojokerto 